\begin{tabular}{l|c|c} 
Journal of Social Studies Education Research & \\
Sosyal Bilgiler Eğitimi Araştırmaları Dergisi & 2017:8 (2), 161-177 & \\
\hline
\end{tabular}

\title{
Formation of Students' Professional Self-Actualization in Modern Educational Environment
}

\author{
Nadezhda A. Dmitrienko ${ }^{1}$, Marina A. Gorbina ${ }^{2}$, Natalya F. Porozhnyak ${ }^{3}$, Tatyana V. Trusova ${ }^{4}$, \\ Tatyana G. Konovalenko 5
}

\begin{abstract}
The research relevance of the paper is determined by social demands in highly qualified specialists with abilities to professional growth. In this regard, the article is aimed at developing students' professional self-actualization in modern educational environment. The article presents authors' technology of developing students' consciousness indicating higher levels of students' professional selfactualization. Leading research methods are: theoretical analyses, induction and deduction, systematic and structural analysis, methods of indirect and direct pedagogic observation, expert evaluation and experimental testing (experimental questionnaires and review). Materials of the article are of practical value for teachers, students and people who are interested in practical ways of self-organizing personal and professional development in modern educational environment of technical university.
\end{abstract}

Keywords: self-actualization, self-actualized personality, communicative creativity, personal position, pedagogic technology, educational environment, motivation.

\section{Introduction}

The present article deals with the problem of improving professional education quality which is closely connected with formation of students' professional self -actualization in modern educational environment. Research subject is the process of forming students' professional selfactualization in education process of learning foreign languages. The need to form students' professional self-actualization is known as a way of improving professional education as

\footnotetext{
${ }^{1}$ Assoc. Prof., Candidate of Pedagogy, Institute of Service and Business (branch) of Don State Technical University in Shakhty, stilist4485@mail.ru

${ }^{2}$ Senior Lecturer, Institute of Service and Business (branch) of Don State Technical University in Shakhty, Marina77@mail.ru

${ }^{3}$ Senior Lecturer, Institute of Service and Business (branch) of Don State Technical University in Shakhty, Natasha555@mail.ru

${ }^{4}$ Senior Lecturer, Institute of Service and Business (branch) of Don State Technical University in Shakhty, Tatyana59@mail.ru

${ }^{5}$ Assoc. Prof., Candidate of Philology, Institute of Service and Business (branch) of Don State Technical University in Shakhty, Kashirochka123@mail.ru
} 
students' personal and professional growth and can be explained by students' motivation and needs, social expectations, and modern requirements to professional education. Meaningful cognitive, professional and cultural components of educational environment are supposed to enhance students' communicative creativity thus improving educational results.

The complexity of the research subject determines the need of using comparative historical analyses of Soviet and post-Soviet traditional pedagogical paradigm to determine humanistic essence of professional self-actualization in modern educational environment. It is important for investigating holistic pedagogical conditions of forming students' professional selfactualization and for eliminating significant gaps and disadvantages of former pedagogic approaches. Traditional pedagogic methodology of Soviet period was aimed at forming significant personal features of a comprehensively developed specialist. Though pedagogic meaning of the concept was considered to be humanistic, the lack of adequate pedagogical explanation and technology implementing the aim in education environment gave birth to a lot of problems. So, holistic aim failed but the problem is still urgent in modern education.

(Bondarevskaya \& Kulnevitch, 1999).

Modern scholars' attention (Gurov \& Seliukova,1996, Didenko \& Klyucharev, 2013, Sulimova, 1996, Talyzina, 2001) is still concentrated on the formation of students' selfactualization in the educational environment by means of increasing a number of pedagogic techniques and tools as external pedagogic consistients of educational process while internal value-semantic mechanisms of students' development are still beyond the research frames.

In particular, it is known that formation of students' professional self-actualization is based on internal sources of development defined by students' synergetic self-developing abilities to improve and form professional knowledge, to initiate new creative ways of working abilities and innovative decision making methods in modern educational environment (Bespalko, 1980, Reshetova, 1985, Zorina, 1996).

The urgency of professional self-actualization is stressed by modern requirements, educational documents, researchers' interests to the problem of improving professional education. It must be pointed out that professional self-actualization is included in students' general professional competence characteristics (Kochetov, 1996, Ruvinskiy \& Kobylecki, 1995) and is usually defined by self-regulated students' educational activity (Kovalev, 1970, Semenov \& Stepanov, 1983, Yigit, 2017). Taking into account synergetic parameters of self-actualization, 
the researchers refer to pedagogical synergy (Budanov, 1996, Zorina, 1996, Knyazeva, 2016, Kulnevich, 1999, Sheveleva, 1996, Barnes, 2011) to explain students'self-organizing learning strategy. Extrapolating synergy principles into the study, the researchers point out that pedagogic process of forming students' professional self-actualization can be represented as students' selforganizing communicative activity determined and regulated by internal sources (students' motivation, communication creativity, consciousness) but stimultated by external sources of pedagogical conditions and technology in modern educational environment.

\section{Literature Review}

\section{Theory of professional self-actualization}

Having analyzed papers dealing with self-actualization, the researchers of the present article point out those studies that can clarify pedagogical essence of the research subject and meet authors' approach to formation of students' professional self- actualization in modern educational environment. Many scientists stress the significance of students' motivation indicating students' learning directions (intentions) to form professional self -actualization and determining intensity of its manifestation in educational environment (Perfilyeva, 2008). These two basic parameters describe educational process of students' development as effective education activity in case of ideal coincidence of four developing stages: violence, manipulation, non-action and self-actualization.

I.R. Prigozhin (1991) noted the significance of synergetic coercion in developing students' self-actualization as a way of making students overcome inner hesitations and personal problems. Manipulation is "a good pedagogic instrument of forming students' motivation to selfactualization" (Prigozhin \& Nicolis, 1997, p. 46). Containing negative shadow, pedagogic manipulation encourages students to take quick communicative and professional decisions to overcome different personal problems known as students' uncertainty and insecurity in modern education environment. Manipulation, non-action and violence are explained in pedagogic literature as external sources stimulating students' internal sources (students' consciousness and motivation).

The concept of "self-actualization" has become popular in scientific literature due to humanistic psychology, where this concept is explained as a result of personal development and personal needs and abilities to implement individual potentials in any significant activity. The most popular and detailed humanistic theory of developing people's self-actualization is carried 
out by A.H. Maslow (1969a), who defines self-actualization as one of the main human needs. The scientist distinguishes self- actualization out of other human needs due to resultative efficiency of personal and professional development and calls it a source of students' personal and professional growth. A.H. Maslow (1969b) believes that self- actualization is typical for most people and it can be developed under certain influence of social conditions. However, the scientist points out that that social and cultural components of education process often suppress person's self-actualization (due to cultural standards accepted in the society). Therefore, to form self-actualization in educational environment, the teachers must appeal to students' systems of values as pedagogic support of students' self-actualization (Maslow, 1969b, p. 201). In the context of the research problem under consideration professional self-actualization is considered to be basic students" needs to become "a functioning personality" (Rogers, 2007, p. 256).

Many scientists study self-actualization as sustainable integrated personal characteristics (Slastenin \& Podymova, 1997, Markova et al., 1983), as effective way of improving personal growth and professional competences (Vyatkin, et al., 2013), as a conscious way of person's existence, as learning strategy of forming competent specialists (Abulkhanova-Slavskaya, 1981, Berikov \& Burns, 1986, Verbitsky, 1991, Slastenin \& Podymova, 1997, Petelina, 2001), as students' professional self-organization (Leontyev, 1985, Self-regulation and forecasting of social behavior of the person, 1987, Antsyferova, 1973, Kulnevich, 1999, Budanov, 1996).

There are three main contexts of researching self-actualization in scientific literature: 1) to describe person's psychological and moral health; 2) to characterize person's emotional experience (happiness in achieving personal goals), 3) to explain personal needs and inner motives (Leontyev, 1987), to describe students' subjectivity (Petrovsky, 1996). But despite a great scientific interest to this problem, the idea of forming professional self-actualization in modern educational environment has not become the subject of special studies yet (Andrienko, 2001, p. 34).

Theoretical analyses of students' professional self-actualization can help the researchers to describe and sufficiently improve a unique nature of students' personal development (Maslow, 1969b) and change educational aims, pedagogic approaches, methods and principles. The authors of the paper suppose that formation of students' professional self-actualization is reflected in students' consciousness activity as basic personal structures and can be developed in communicative creativity stimulated by communicative situations as students' self-organizing 
learning strategy to overcome various communicative and personal problems and hardships. In this case students' self-actualization is one of the main conditions of person's survival in the complex regalia of everyday life being developed in modern education environment. In general, literature review proves the relevance of the present study and stimulates the researchers' interest to eliminate existing contradictions in modern education environment.

\section{Modelling self-actualization in modern educational environment}

Authors' innovative model of forming students' professional self-actualization in education environment is reflected in the authors' pedagogic technology based on concepts correlation of self-actualization, creativity and professional self-organization (Maturana, 2006). Synergy integration describes pedagogic conditions of students' communicative creativity as self-organizing process realized in communicative situations of learning foreign languages. Students' co-creative activity is the basic synergetic integrative principle involving students in modeling various open communicative situations in modern educational environment of learning foreign languages. Thus students' creative potentials are revealed in modeling communicative situations combining cognitive, cultural, professional, communicative and personal values of modern educational environment. In this case pedagogical technology becomes a very important instrument compared with life situations changing students' minds and developing synergetic thinking and students' consciousness (Dmitrienko \& Ershova, 2017).

Self-organized process is stimulated by pedagogic tools: manipulation, violence and non action being changeable synergetic parameters regulated by communicative situations making students overcome inner hesitations, and personal problems. Pedagogic principles are picked out by the authors among the claimed pedagogical approaches: cultural-semantic orientation, humanization, synergy, value orientation, cultural communicative content, integration and complementarity. As students' self-actualization is considered to be a pedagogic principle, so the authors of the study appeal to it to describe personal trajectory of self-developing students' continuous professional growth. Paying attention to the aim of the study three types of communicative situations are designed and tested by the researchers to outline distinguish features of the authors' pedagogic technology:

1) problem and contradictive communicative situations imitating conflict situations contain different problems, contradictive facts and open information meet the interests and needs 
of students' age and initiating students' criticality, independence and autonomy as invariant thinking;

2) professional communicative situations imitating future professional activity initiating students' creativity, self-control and empathy;

3) everyday communicative situations imitating modern problems of social reality based on variety of cultural, personal and moral values initiating students' moral choice and life plans, forming motivation, system of values and humanistic attitude to life.

\section{Methodological Framework}

\section{Research design and methods}

The complexity of research tasks determined the need of using a combination of methods including comparative analyses, induction and deduction, generalization of key concepts and approaches. Experimental methods are based on direct and indirect pedagogical observation, tests and questionnaires to determine students' levels of self-actualization at different stages of experimental work and to prove the efficiency of the authors' pedagogic technology.

In order to investigate students' motives and interests in professional self-actualization a semi-structured interview was organized by the researchers at practical classes of learning foreign languages. The results proved students' significant interest in professional growth by means of communicative creativity in educational activity. To gain more in-depth information about students' motivation improving levels of students' self- actualization and to learn more about effective pedagogical and communicative situations facilitating or hampering students' professional self-actualization in education environment of technical university, a set of questionnaires was applied. The final results demonstrated that $78 \%$ of interviewed students were highly motivated in forming higher levels of professional self-actualization in educational environment of technical university, $20 \%$ of them had low motivation and wanted to do it later and $2 \%$ of the students were indifferent to personal development results. Corresponding to the research tasks, the interview participants were asked to point communicative situations as (1) stimulating or (2) hampering students' personal and professional development. Subsequently, respondents were asked to rank them as descending degree of importance factors of communicative creativity. As students' self-actualization is the result of inner students' activity so it can be estimated as consciousness activity reflected in innovations in students' personal structures (reflexion, motivation, autonomy, self-control) and can be diagnosed in education 
process. Self-actualization test was applied to evaluate different levels of students' selfactualization in experimental and control groups.

\section{Participants}

The research study was conducted for three years in educational environment of the Institute of Service and Business (branch) of Don State Technical University from 2013 to 2016. 356 students from different faculties participated in the study. They had different levels of motivation as they were randomly selected from various faculties of the first and second courses. Thus there were 6 experimental groups and 8 control groups of students. It should be noted that the authors of the study do not take into consideration, gender, national and social differences of selected students.

\section{Efficiency of self-actualization in communicative creativity}

The main criterion to evaluate the efficiency of students' self-actualization in communicative situations of learning foreign languages is students' communicative creativity implemented in modern educational environment of technical university.

The degree of communicative creativity was evaluated by direct and indirect pedagogic observation methods at practical classes of learning foreign languages. The results showed students' innovative communicative competences expressed in communicative activity having quantitative expression and characterized as unusual way of communicative combinations, assimilation and complementarity (adding information) being indicators of students' professional self-actualization. Individual results of developing self-actualization were ranged into three levels, low, middle and high to indicate efficiency and quality of developed students' characteristics. Thus, two types of indicators (qualitative and quantitative) were applied in experimental work.

Students' professional self-actualization levels were assessed in accordance to the authors' descriptive characteristics of communicative creativity determined by students' communicative competences:

- Students can define communicative problems, point out contradictive details, formulate communicative goals and objectives; determine perspective ways of gaining communicative results, forecast and overcome possible problems and hesitations under changing communicative situations, demonstrating higher levels of communicative self-development (self-control; motivation); 
- Students can analyze and define relevant professional, cultural valuable information compare and identify them with personal peculiarities to form personal value systems, professional and cultural standards, demonstrate linguistic skills to process foreign information and systematize it in communicative creativity (flexibility, criticality, contact and sensitivity);

- Students can demonstrate communicative independence, originality, free choice of communicative means as self-respect and respect to communicative partners in communicative dialogues (creativity, self-acceptance, self-esteem, independence and freedom);

- Students can solve various communicative problems and communicative transformations, find outsider positions (collisions, time competence, holistic perception of life);

- Students can support communicative partners, predict and evaluate communicative perspectives and goals (empathy and sensitivity).

Communicative creativity has quantitative and qualitative statistical characteristics and can be evaluated as innovative statements, heuristic communicative style complementarity.

The data was collected as clusters in communicative activity at practical classes of learning foreign languages and then obtained results were analyzed according to Pierson correlation coefficient.

\section{Results and Discussion}

The results were received as qualitative and quantitative changes in students' levels of self-actualization done by researchers during indirect and direct pedagogic observation. They were registered as special diagnostic tools. All participants of experimental work were asked to fulfill self-actualization test (SAT) (Shostrom, 1968). The survey was conducted individually with each student to determine personal points at each scale of the test (the highest point is 100). Then the received students' results were compared with teachers' results and the mean scores were defined as standard points. This methodological procedure was aimed at denoting and comparing personal levels of self-actualization reflected as changes in various scales for every tested students of experimental and control groups.

The practice of using SAT for defining students' professional self-actualization resulted in various studies showed that students' high levels of self-actualization are 55-70 points, while 45-55 points are considered to be statistical mean points of students' self-actualization (Shostrom, 1968). Using SAT in the present research the authors had a fine chance to trace dynamical changes in students' self-actualization denoting students' individual and professional 
growth in modern educational environment. Processing procedure was an important part of experimental work as it was based on a double estimation, self-estimation and teachers' evaluation, regarded as subjective and objective evaluation results. Students' individual learning strategy was realized as personal trajectory of learning efficiency (corresponding to personal peculiarities as holistic nature component) and was graphically expressed and presented in personal registers as personal results to be compared with. So students had an opportunity to put personal aims in learning foreign languages, determining terms of improving self-actualization and predicting learning results. Students of experimental groups were informed about the significance of professional self-actualization in education activity and were told about the ways of pedagogic tools improving self-organizing effects.

Students' awareness added them motivation degree and inspired them to get higher results. The participants were also asked to specify the effects of experiment study on their life satisfaction using choices: "never agree, rarely agree, sometimes agree, agree, and totally agree". According to the descriptive analysis of students' life satisfaction the mean point was denoted 4,65 (as an agree level).

Every student of experimental groups demonstrated a certain increase in various scales determining levels of professional self-actualization at the end of the experiment. Received results can be compared with students' indicators of self-actualization levels at initial stages of the experiment. These changes are reflected in Table 1, recording growth of each student in experimental groups and comparing them with students' results in control groups. Table 1 contains comparative results of students' professional self-actualization in experimental and control groups where M1 is used to indicate students' levels at the starting stage of the experiment and M2 to determine its final values characterizing developed students' professional self-actualization.

Table 1

Comparison of Experimental Results Indicating Students' Self-Aactualization Levels in Control and Experimental Groups

\begin{tabular}{lcccc}
\hline Scales & $\begin{array}{l}\text { Students of experimental groups } \\
\text { starting (M1) final (M2) } \\
\text { values) }\end{array}$ & $\begin{array}{l}\text { Students of control groups } \\
\text { (mean } \\
\text { starting (M1) final (M2) } \\
\text { values) }\end{array}$ & (mean \\
\cline { 2 - 5 } & $\mathbf{M ~ 1}$ & $\mathbf{M ~ 2}$ & $\mathbf{M ~ 1 ~}$ & M 2 \\
\hline $\begin{array}{l}\text { 1. time } \\
\text { competence }\end{array}$ & 7,8 & 7,9 & 2,66 & 7,2 \\
\hline
\end{tabular}




\begin{tabular}{lcccc}
\hline 2. self-control & 46,8 & 47,6 & 6,76 & 46,4 \\
\hline $\begin{array}{l}\text { 3. value } \\
\text { independence }\end{array}$ & 11,0 & 11,4 & 3,31 & 10,7 \\
\hline $\begin{array}{l}\text { 4.communicative } \\
\text { flexibility }\end{array}$ & 14,8 & 13,5 & 3,74 & 13,4 \\
\hline 5. sensitivity & 6,4 & 6,7 & 2,64 & 7,5 \\
\hline 6. self-esteem & 6,3 & 7,1 & 2,60 & 6,6 \\
\hline 7. contact & 8,6 & 9,2 & 2,94 & 8,4 \\
\hline 8. self-acceptance & 10,4 & 14,4 & 3,17 & 10,1 \\
\hline 9.freedom & 4,8 & 4,9 & 2,04 & 4,1 \\
\hline 10. synergy & 4 & 3,6 & 1,76 & 3,7 \\
\hline $\begin{array}{l}\text { 11. aggression } \\
\text { acceptance }\end{array}$ & 2,79 & 7,8 & 2,84 & 8,8 \\
\hline $\begin{array}{l}\text { 12. self- } \\
\text { actualization }\end{array}$ & 3,17 & 10,1 & 4,16 & 5,8 \\
\hline $\begin{array}{l}\text { 13. holistic } \\
\text { perception of life }\end{array}$ & 1,44 & 6 & 2,30 & 4,8 \\
\hline 14. creativity & 2,54 & 6,5 & 2,50 & 7 \\
\hline 15. support & 2,45 & 4.8 & 2,12 & 5,6 \\
\hline 16. independence & 4,6 & 12,8 & 4,5 & 6,7 \\
\hline 17. self-image & 6,4 & 11,7 & 5,9 & 7,5 \\
\hline
\end{tabular}

The calculated points of $t$ exceed the mean points given in Table 1 in both scales (if two scales are taken): on scale of support and communicative flexibility. Thus taken into account received results it is possible to assert with confidence that the authors' technology affects students' self-actualization in experimental groups though it effectively reduces the degree of students' communicative flexibility especially at starting stages of experimental work. It may be explained by accumulative effect of students' communicative development. In addition, the changes are seen in students' indicators of experimental groups demonstrating increased indicators in scales of self-acceptance, acceptance while students in control groups willingly demonstrate interpersonal sensitivity (the scale aggression and sociability). Thus, the authors' technology of modeling communicative situations helps students to accept their own unique nature, to form motives, to respect inner beings and improve professional self-actualization. Comparative analyses of students' results among students of experimental and control groups were conducted at certain stages of the experiment where mean point of $t-$ test is $(\&<0.05$, while in the $t$ table is 2.04 determining communicative freedom equal to 37 points), thus 
significant differences are observed among students on both scales (time competence and support), as well as on additional scale - communicative flexibility.

In the beginning of experimental work, students of experimental groups were tested and the results they demonstrated showed that they had low indicators of holistic perception of life but greater independence of values and communicative flexibility. This fact can be explained by priorities and preferences in students' communicative orientations and personal communicative strategy of development. But, final results of experimental work demonstrated significant alignment in all testing scales among students of experimental groups indicating higher levels of professional self-actualization.

The results confirmed a widening gap in statistically reliable indicators among students of experimental and control groups. On the scales of self-acceptance, acceptance of aggression and contact significant changes were registered at the final stage of experimental work influenced resulting changes. Statistically significant differences appeared in following scales: value orientations, self-esteem and self- actualization. Thus, students with initially higher level of selfactualization in control groups show mean increase points in three scales - two basic and one additional, while the students of experimental groups were evaluated by seven scales (one basic and six additional).

Pedagogic observation showed that students of experimental groups have higher indicators in all scales reflecting higher degree of students' self-actualization as high levels of self-image, independence, freedom etc. at the expense of decreasing points in scales of sociability, and communicative flexibility resulted as personal problems with communicative competences as self-expression in foreign languages. Students could easily express their independent opinions, and were quick to find innovative invariant communicative decision based on greater internal freedom, self-respect and self-acceptance.

However, the obtained data was not enough for full confidence in technology efficiency. In this regard, clarifying diagnostic procedure was applied to identify direct and indirect changes in personal structures of consciousness as being indicators of students' self-actualization. Preliminary results for the second group of tests were obtained by means of individual testing and observation of students' results as self-assessment characteristics: results presented proved positive results of experimental work. Dynamics of students' changes can be registered mostly 
between positive indicators as qualitative changes in personal structures of consciousness among students of experimental groups.

Thus, students 1 and 3 demonstrated high level of motivation at the starting stage and at the final stage of experimental testing both students showed a significant increase in motivation levels. Students qualitative changes were estimated by four scales with increased indicators (one basic and three additional). Table 2 shows the results of the student 2 with low motivation level at the beginning of the experiment and a significant increase in scales of motivation, reflection, self-assessment and criticality at the final stage of the experiment. Communicative competences were estimated in communicative creativity as communicative originality and innovative ways of students' self-expression, manifestation frequency indicators prove increased levels of students' professional and communicative competences as professionally significant qualities having humanistic values.

Table 2

Dynamics of developing students' professional self-actualization

\begin{tabular}{lllllllllll}
\hline Scales & \multicolumn{2}{l}{$\begin{array}{l}\text { Starting } \\
\text { the experiment }\end{array}$} & $\begin{array}{l}\text { stage } \\
\text { of }\end{array}$ & $\begin{array}{l}\text { Finishing stage of } \\
\text { the experiment }\end{array}$ & Changing dynamics \\
\hline $\begin{array}{l}\text { Personal } \\
\text { structures }\end{array}$ & St. 1 & St. 2 & St. 3 & St .1 & St. 2 & St. 3 & St. 1 & St. 2 & St. 3 \\
\hline Motivation & 43 & 37 & 52 & 54 & 50 & 64 & +11 & +15 & +12 \\
\hline Criticality & 52 & 46 & 64 & 57 & 59 & 71 & +5 & +11 & +7 \\
\hline Reflexion & 62 & 41 & 59 & 69 & 56 & 79 & +7 & +15 & +20 \\
\hline Self-assesment & 41 & 38 & 51 & 53 & 46 & 68 & +12 & +8 & +17 \\
\hline
\end{tabular}

The first part of experimental work was intended to point criterion justification; a wide range of diagnostic techniques has been implemented. The second part of experimental work was connected with experiment organization and it was conducted as applying set of questionnaires adapted to the aim of the study to estimate initial states of students' qualities and characteristics and communicative competences in specially designed communicative situations. The third stage was a formative experiment intended to define final results. The purpose of experimental work was to identify the effectiveness of the proposed technological innovations, tracking dynamics 
and forecasting students' future professional growth. At this stage obtained results were comprehensively summarized to prove initial pedagogic supposition. It should be noted that deviation in experimental results do not exceed experimental time duration thus confirming overall repeatability of results in all diagnostic techniques. In this regard, the researchers present the results of ascertaining methods at control stages of experiment in unified Table 1 and Table 2 demonstrating relevant indicators of indirect and direct diagnostic methods. Subsequent changes in levels and degree of professional self-actualization are typical for students of experimental groups. Three-time repeatability of results also underlines dynamical changes in students' levels of professional self-actualization in experimental groups in comparison with students of control groups.

\section{Conclusion}

Literature analyses proved authors' supposition that to develop personal qualities and characteristics like self-actualization a pedagogic technology (Burns \& Flam, 1987) must be designed as a general education model, combining and incorporating all educational components in cultural educational environment to stimulate students' self-organizing processes to make them go beyond education frames of a single subject - "Foreign language". The authors' technology of modeling communicative situations differs from existed education models of former Soviet and post-Soviet periods as it is based on holistic ideas and essences, on coincidence of pedagogic approaches, criteria and principles of personal oriented, cultural, communicative and synergetic methodology stimulating students' individual development, creativity and self-organization thus eliminating contradictions and gaps in modern professional educational environment.

The authors' pedagogic technology is designed as students' self- organized learning strategy implemented in communicative creativity to ensure permanent character of students' self-developing process as a unique picture of personal self-development changing usual education and communicative position of students and teachers and incorporates education components into unified education model. This is done due to students' co-creativity and communicative creativity in learning foreign languages where subjective activity is connected with purposeful transformation of communicative situations broadening subjective communicative experience. Education environment is a synthesis mechanism to identify students' perspective self-organizing learning strategy. 
Innovative abilities of students' self-actualization in experimental groups are closely connected with students' consciousness activity stimulated by communicative situations. So the main principle of technological instrument is co-creation of students and teachers in education environment where a person cultivates personal abilities in education design of communicative situations when participating in communicative creative activity. The innovative self-organized learning strategy is stimulated by modeling communicative situations containing basis for spiritual and moral assessment as moral imperatives.

Theoretical analyses and experimental results proved the efficiency of designed technology. Students of experimental groups participated in three types of modeling communicative situations and demonstrated higher levels of professional self-actualization in communicative creativity. In other words, positive results of experimental work proved the efficiency of pedagogic technology being a holistic self-organizing learning strategy emphasizing professional self-actualization in modern education environment.

Synergy methodology significally expands students' learning abilities transforming communicative situations into self-organizing communicative strategy where the students become real creators of education process and active subjects to be responsible for education results.

Innovative technology of forming students' professional self-actualization differs from traditional technologies as it is mobile educational model which can be easily adapted to the students' and subjects' peculiarities while traditional technologies are usually based on teacher's authority and direct knowledge transmition.

Since the studied problem is complex, the work should be continued to ensure interdisciplinarity to expand research horizons: point out and compare gender, age and social differences of self-actualization in the educational environment. 


\section{References}

Abulkhanova-Slavskaya, K.A. (1981). Development of a personality in the process of life. In: Psychology of formation and development of personality. Moscow: Science, 19-44. Andrienko, E.V. (2001). Professional pedagogical education and personal development of teachers: textbook. Novosibirsk: NSPU Publishing House, 34.

Antsyferova, L.I. (1973). Psychology of self-actualizing personality in the works of Abraham Maslow. Questions of Psychology, 4, 173-180.

Barnes, G. (2011). I Can Let My Soul Soar. An Appreciation for the Idea of Heinz von Foerster and his Circle of Ideas. Paper presented at the conference «Self-Organization and Emergence» devoted to the $100^{\text {th }}$ anniversary of H. von Foerster, Vienna, 62-65.

Berikov,V.V. \& Burns, R. (1986). Development of education. Moscow: Progress, 421.

Bespalko, V.P. (1980). Problems of developing pedagogical systems. Moscow, 34-36.

Bondarevskaya, E.V. \& Kulnevich, S.V. (1999). Pedagogy: personality in humanistic theories and systems of education. Moscow-Rostov-on-Don.

Budanov, V.G. (1996). Era of bifurcations and synergy in education. Moscow, 42.

Burns, T. \& Flam, H. (1987). The Shaping of Social Organization. Beverly Hills: Sage, 34-56.

Didenko, D.V. \& Klyucharev, G.A. (2013). Vocational education in Russia: ways of catch-up modernization and innovation. Issues of Education, 1, 183-204.

Dmitrienko, N.A. \& Ershova, S.I. (2017). Forming the Students' Synergetic Thinking in the Synergetic Reality of Communicative Situations. Man in India, 97(5), 13-32.

Gurov, V.N. \& Seliukova L.I. (1996). Socialization of the personality: social worker, family and school. Stavropol, 120.

Kochetov, A.I. (1996). Culture of pedagogic research. Minsk, 312.

Kovalev, A.G. (1970). Psychology of personality. Moscow, 212.

Knyazeva, E.N. (2016). The wisdom of the environment: ideas of F. de Saussure, F. Guattari, R. Thomas in the context of the development of biosemiotics. Philosophical Sciences, 9, 6176.

Kulnevich, S.V. (1999). Pedagogics of self-organization: the features of transition to post-nonclassical educational theory. New of the Russian Academy of Education, 3, 41-48.

Leontyev, D.A. (1987). The development of the idea of self-actualization in the works of A. Maslow. Questions of Psychology, 3, 150-158. 
Markova, A.K., Orlov, A.B. \& Fridman, L.M. (1983). Motivation and education of the students. Moscow: Pedagogy, 67.

Maslow, A.H. (1969a). Notes on Being-psychology. In: Readings in humanistic psychology. Sutich, A.J., Vich, M.A. (eds). N.Y.: Free Press, 45-47.

Maslow, A.H. (1969b). A theory of metamotivation: The biological rooting of the value-life. In: Readings in humanistic psychology. Sutich, A.J., Vich, M.A. (eds). N.Y.: Free Press, 201204.

Maturana, H.R. (2006). Self-consciousness: How? When? Where? Constructivist Foundations, 1(3), 34-36.

Perfilyeva, M.B. (2008). Managing staff loyalty. Prague: ChTU Publishing House, 23.

Petelina, V.N. (2010). Socio-cultural space of a science as the orientation field of professional identity of student. URL: http://psyedu.ru/authors/a1879.phtml

Petrovsky, V.A. (1996). Subjectivity: a new paradigm in education. /Science and Education, 3, 100-105.

Prigozhin, I.R. \& Nicolis, G. (1997). Complexity of transferring knowledge. In: Synergetics and Psychology. Texts. Vol.1. Moscow: MSU «Union», 62-93.

Prigozhin, I.R. (1991). Philosophy of instability. Problems of Philosophy, 6, 46.

Reshetova, Z.Ya. (1985). Psychological foundations of professional education. Moscow: MSU, 204.

Rogers, C. (2007). The necessary and sufficient conditions of therapeutic personality change. Psychotherapy: Theory, Research, Practice, Training, 44 (3), 256.

Ruvinskiy, L.I. \& Kobylecki, I. (1985). Basics of pedagogy. Moscow: «Prosveschenie». Self-regulation and forecasting of social behavior of the person. (1979). Ed. V.A. Yadov. Leningrad: Science.

Semenov, I.N. \& Stepanov, S.Y. (1983). Reflection and organization of creative thinking and self-development. Questions of Psychology, 2, 35-42.

Slastenin, V.A. \& Podymova, L.S. (1997). Pedagogy: innovative activities. Moscow: Master. Sheveleva, S.S. (1997). To the formation of synergetic model of education. Social Sciences and Modernity, 1, 125-133.

Shostrom, E.L. (1968). Time as integrating factor. In: The course of human life. Buhler Ch., Massarik F. (eds). N.Y.: Springer, 351-359. 
Sulimova, T.S. (1996). Social work and constructive conflict resolution. Moscow: Institute of Practical Psychology.

Talyzina, N.F. (2001). An active approach to the mechanisms of communication. Questions of Psychology, 9, 3-16.

Verbitsky, A.A. (1991). Active learning in higher school: the Contextual approach. Moscow, 207.

Vyatkin, B.A., Shchukin, M.P. \& Merlin, V.S. (2013). About the Problem of Psychological Training in the Pedagogical Higher School (Celebrating the 115th Anniversary of the Scientist). Education and Science Journal, 1(1), 146-156.

Yigit, M.F. (2017). Value Priorities of Public and Private University Students. Research in Social Sciences and Technology, 2(1). URL: http://ressat.org/index.php/ressat/article/view/38/19

Zorina, L.Y. (1996). A reflection of the ideas of self-organization in the content of education. Pedagogy, 4, 105-109. 